\title{
APPLICATION OF A JOYFUL LEARNING STRATEGY BASED ON HUMOR COMMUNICATION TO IMPROVE THE INTERESTS AND ACHIEVEMENTS OF LEARNING ENGLISH
}

\author{
Wahyuni. S, Muh. Rezky Naim \\ STIE (State College Economic Studies) Yapman Majene \\ Address Jl. Jend. Sudirman No.1 Majene Indonesia \\ wahyuni@stieyapman.ac.id
}

\begin{abstract}
Enhancing the quality of education in particular to improve the quality of students, a teacher must also improve their selves to delivering better learning innovations and one of those efforts by Using appropriate learning strategies so that the material delivered by the teacher can be young to be understood by students. The strategy in question is communicating with humor. The use of humor in the learning process is a medium for educators to students in transferring their knowledge because with humor can create better communication so that the classroom atmosphere is more comfortable. The purpose of this research had three important stages, including 1) to find out a lecture communication with students can be better so that through communication with humor can reduce the problem of lecturers with Students of which currently margined violence cases between lecturers and students, 2) increased achievement of learners learning because through humor communication through joy full learning students will learn more relaxed without any pressure so Easier to do tasks, 3) increased achievement and interest in students 'study in English courses as a General basic course. The method used in this research was the experimental Research design (quasi) method using the control class and experiment class. The study used three research instruments: interview, student observation (participant observation), student learning results. The results showed that there were differences in the pre-test and post-test values in experimental classes and the control class as well as the results of independent analysis of T-test result of Sig (2-tailed) 0.00 where the result of this value is smaller than 0.05 . Indicates there is a significant difference between the Ecperimental and control classes in terms of application of the Stratei Learning Joyfull Learning-based humor to increase the interest and achievement of English learning as a public course in students STIE Yapman Majene.
\end{abstract}

Key Words: Joyfull learning, humor communication, interest, achievement, learning English 


\section{INTRODUCTION}

Many educators who have spent countless hours of learning are only to speak in front of the class without giving any effect on the student or student knowledge. As if the knowledge transferred to the students was simply entered from the left ear and out of the right ear, without any knowledge captured by the students or students, in other words the process of learning and teaching is only as a process Should be completed immediately without any results. That's a little picture of the state of education that expects modern education but without the support of the actors themselves. Ironically, many teachers or lecturers are unaware of the matter. Especially for the lecturers who teach general basic courses such as English courses in the School of Economics of Yapman Majene (STIE Yapman Majene), which is high school in West Sulawesi province based on management Think that English is a course that does not require an extra process in order to produce this extraordinary out put because English courses are only taught in the first semester. Coupled with a lack of interest in students of STIE Yapman majene in learning English. They assume that this course is not a continuation with other subjects in the future and the workforce does not require them to speak English. This is inversely proportional to the current working world conditions. Many Persero companies are either private or state-owned enterprises that open up many job opportunities for graduate economics graduates by adding qualifications or criteria capable of using English appropriately. By this it can be a center of attention for lecturers and students to be more active pro in the teaching and learning process of English courses.
Based on the results of the above observations can be concluded teachers of English language courses must be more creative to choose a method or strategy in teaching English in the classroom so that students also feel happy and enthusiastic in Learn. And the right strategy is a fun learning strategy that uses humor to improve student interest and learning achievement in English.

Humor makes one can observe, feel or express humor, should have a sense of humor. Sense of humor is something universal that is a concept of various fields that have many definitions. The American Heritage Dictionary defines the sense of humor as the ability to observe, enjoy, or express what is funny (Apte in Hafsah, 2014). Subsequently Martin in Hafsah (2014) defines the sense of humor as a different individual habit in every behaviour, experience, feeling, pleasure, attitude, ability to connect something with pleasure, laughter, Joking and so on.

Using humor in the classroom is rational because through a method of humor can improve the ability of vocabulary (your words), grammar and wording (composition) (Rebekka Krauze, 2015). Humor can avoid a person from excessive boredom, reduce stress and anxiety, and fear, improve mood and confidence. Cooper and Sawaf (1999) Inside Arif (2015) stated that a teacher's humor encourages children to be cheerful and joyful and will not feel bored or tired. Bored is a terrible disease in learning. If someone gets bored, the brain will send a signal to the whole body to be unproductive and lazy. This will greatly affect students ' learning achievements. When students are tired of teaching and learning activities, 
students will become unproductive, which will result in the continuation of student learning achievements (Aswad 2017).

Based on the above background can be inferred in the use of humor in the process of teaching learning can make learners more comfortable in class, easier to understand the material taught, and more motivated and not only that just use Humor in the classroom can also establish communication between teachers and students so that tensions can be clear through humor.

\section{REVIEW OF LITERATURE}

\subsection{Joyful Learning through Humor}

Joy Full Learning through Humor is a mindset in the direction made by the teachers to improve the delivery of the material to be easily accepted by the students, so that what the teacher delivered is easy to accept and Dimungkinkankannya can add achievements as well as learning interests of students according to what to expect. Fun interaction and communication between lecturers and students is the most important factor in to receive a fun learning strategy. Whatever effort is made to create a physical environment and build a comfortable atmosphere. One of the exciting forms of interaction and communication that is developing in today's learning is the use of humor, humor turns out to make a positive impact. Humor can even help students to improve their memory, reduce stress especially the learning that is performed during the day, facilitate understanding in various areas of discipline (Supriyasi, 2017).

\subsection{Humor Benefits in the English Classroom}

The education world has evolved rapidly, as the educators have to be more creative with learning strategies, and one of the right strategies is humor. The sense of humor in class is more effective in teaching learning. On one side the students or students will not be bored in the classroom. Humor is a cederung attitude done to evoke a sense of delight and spark laughter. The term derives from the ancient Latin medical term, which teaches that the balance of fluid in the human body, known as humor that is governed by the health and human emotions. There are five benefits of the humor of Husaini Algoyani (www.kompasiana.com). In the book "Joyful Learning Strategy with Humor"; by Darmawangsah, S. T, M. Pd. Darmawangsah (2002) conducted a study of how students are perceptual to the teacher who inserts humor in the Pemebalajaran. The results reveal that the teacher they are happy with is a teacher who has a high sense of humour. The findings of this study have implications for the learning process, both from the teacher's side and the students themselves. This means the teacher or the student itself. This means that teachers should pay close attention to what students are interested in learning and students will benefit if the factors that directly relate to the quality of the teacher's interactions can be mutually fulfilled between them.

Based on the results The study revealed that humor is needed in learning. Students enjoy humor, as they can help melt the atmosphere in a class that they sometimes have to experience in a very long time can be taken as follows: 
1. Humor as a student's attention-brushing. The proper insertion of humor from the teacher can further direct students 'focus on learning materials.

2. Humor helps reduce boredom in learning. This humorous research result can eliminate boredom in learning.

3. Humor helps to melt tension in the classroom. In the opinion of experts that a humorous teacher can enter into all the situations of the students. Allowing a teacher to improvise with humor. Teachers can solve that tense mood by raising humor at the moment of possible.

4. Humor helps overcome physical and mental fatigue in learning.

5. Humor for easy communication and interaction.

6. Build relationships and improve communication

7. Reduce stress

8. Make the lesson more interesting

9. Improve Memory of learning

\subsection{Joyfull Learning Strategy through Humor}

Learning strategy is a way of organizing lesson content, delivery of lessons and management of learning activities using various sources. In Wina Senjaya (2008), suggests that a learning strategy is a learning activity that teachers and students should work on so that the learning goals can be achieved effectively and efficiently. Furthermore, citing the thought of J. R David, Wina Senjaya (2008) mentions that in the learning strategy contained the meaning of planning, meaning that the strategy is essentially still conceptual about the decisions to be taken In a learning implementation. The learning atmosphere will be joyful if students as subjects learn to perform the learning process based on what is desired. The competency-based learning process will be greatly expanded if the teacher gives students or students the freedom and autonomy to choose the activities and learning materials to be implemented. Workers act as facilitators who democratically give directions on the map of the learning process that will take place. The map of the learning process involves the signs that should be offered to students or students.

\section{METHOD}

Research conducted in the High School of Economics (STIE Yapman Majene) of West Sulawesi province. The location of the site is the only one of the oldest management courses in West Sulawesi province, which is not the case. And not only that based on the results of the previous research researchers, almost all students are not interested in learning English as a result of the faculty of lectures given teaching assignments on this subject only just teaching without knowing The absence of an extraordinary put out.

The type of research used in this research is an experimental method (Quasi experimental design) that uses two research classes one acts as an experimental class or that gets the treatment of one as the control class. This research aims to find the result of the implementation of joy-based full learning strategy in improving the interest and 
achievement of English language learning in the students Department of Management STIE Yapman Majene through two tests namely test before and After treatment.

The sampling techniques used in this research are purposive sampling techniques or non-random sampling where researchers determine the sampling by assigning special characteristics that correspond to the research objectives so that Expected to answer the research problem. The sample used in this research is a class that will be given a strategy of joy-based full learning humor L-class with the number of students from 50 people and class $M$ control grade with a total of 50 students. So the total sample on this study was 100 students.

The instrument on the weaver will use several types of test it aims to make the data more valid. The type of test and written test is the first speaking test or speaking performance test.

\section{FINDINGS AND DISCUSSION}

After analyzing the value of student study results in pre-Test and post-test through SPSS 24.0, the results can be described in the table and numbers as follows:

Table 1. Descriptive statistics Pre-Test and PostTest on Experimental class

\begin{tabular}{|l|r|r|r|r|r|}
\hline & \multicolumn{1}{|c|}{$\mathrm{N}$} & \multicolumn{1}{|c|}{ Minimum } & Maximum & Mean & Std. Deviation \\
\cline { 2 - 6 } & Statistic & Statistic & Statistic & & \multicolumn{1}{c|}{ Statistic } \\
\hline Pretest & 50 & 60.00 & 80.00 & 70.60 & 6.197 \\
Posttest & 50 & 70.00 & 100.00 & 81.80 & 7.197 \\
Valid N & 50 & & & & \\
(listwise & 50 & & & & \\
\hline
\end{tabular}

Based on the descriptive statistics as the table shown in Table 4.1 above, it is apparent the difference between the minimum and maximum values on Pretest and post-test for experimental classes. As for the average value before given treatment (pre-Test) 70.60 with a good category while for the value on pot-Test 81.80 with a very good category. Based on the results of the analysis, it can be concluded that there is a difference of students ' ability and achievement before and after treatment in this case is the application of Joyfull learning strategy to increase interest and English Learning Achievement Students STIE Yapman Majene as the course of public lecture.

Figure 1. Histogram of Students' Pre-Test of Experimental class

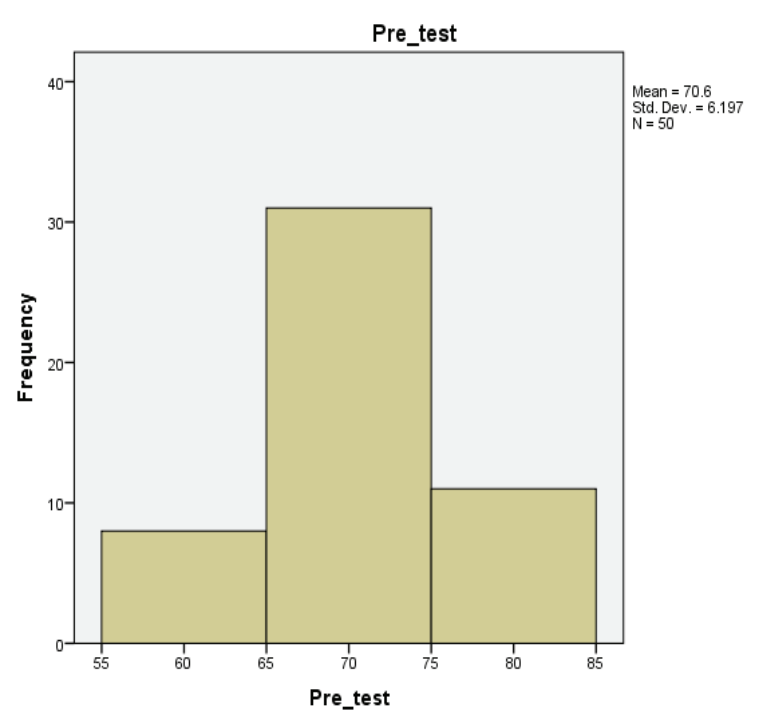


Figure 2. Histogram of Students' Post-Test of Experimental class

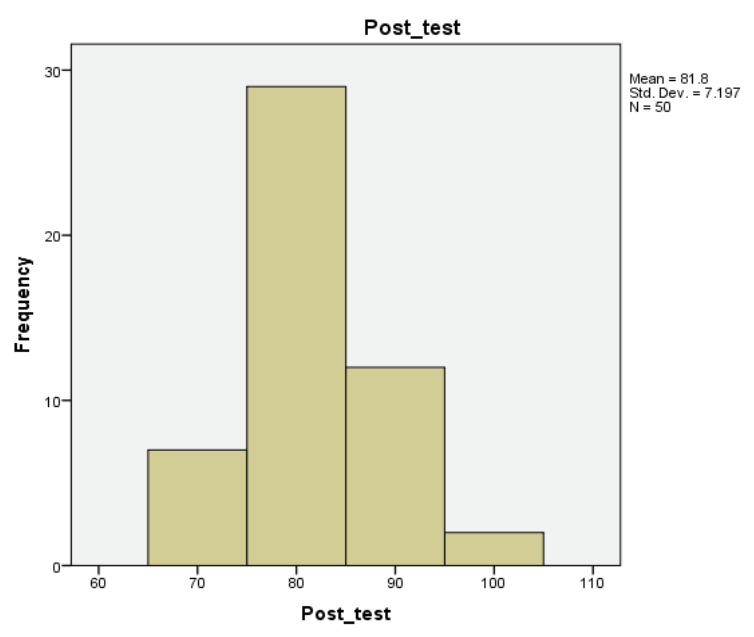

Table 2. Descriptive statistics Pre-Test and PostTest on Control class

\begin{tabular}{|l|r|r|r|r|r|}
\hline & \multicolumn{1}{|c|}{$\mathrm{N}$} & Minimum & Maximum & Mean & Std. Deviation \\
\cline { 2 - 6 } & Statistic & Statistic & \multicolumn{1}{|c|}{ Statistic } & & \multicolumn{1}{c|}{ Statistic } \\
\hline Pretest & 50 & 60.00 & 60.00 & 70.00 & 6.389 \\
Posttest & 50 & 80.00 & 90.00 & 70.70 & 7.590 \\
$\begin{array}{l}\text { Valid N } \\
\text { (listwise }\end{array}$ & 50 & & & & \\
\hline
\end{tabular}

Based on descriptive statistics such as the table shown in table 4.2 above, there is no difference in the minimum and maximum values on Pretest and posttest for control class as for the average value (preTest) 70.00 with a good category while to The value on pot-Test 70.00 with very good categories. Based on the results of the analysis, it can be concluded that there is no difference in student skills and achievements in the control class.
Figure 3. Histogram of Students' Pre-Test of Control class

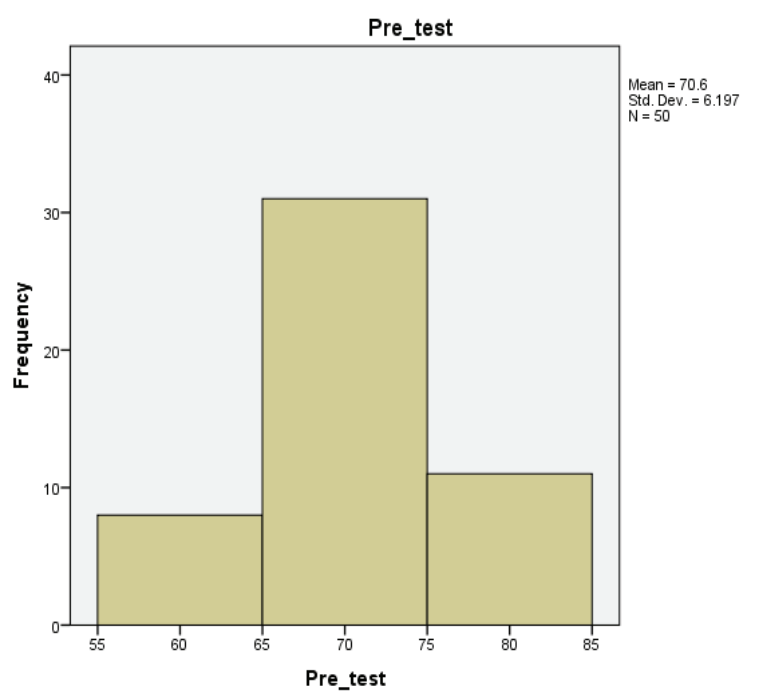

Figure 4. Histogram of Students' Post-Test of Control class

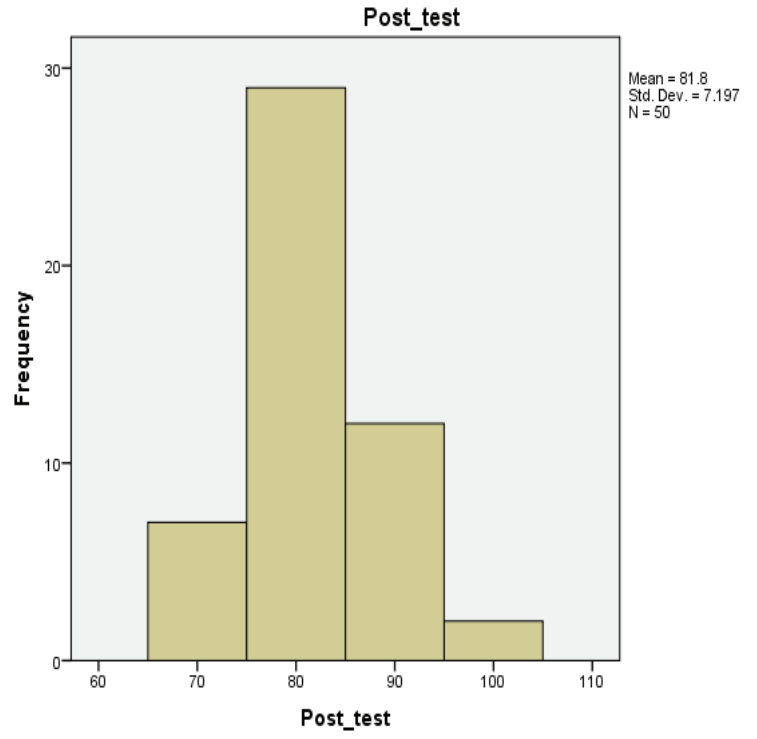


Table 3. Independent Sample t-test of Pre-test

Independent Samples Test

\begin{tabular}{|c|c|c|c|c|c|c|c|c|c|c|}
\hline & \multicolumn{2}{|c|}{$\begin{array}{l}\text { Levene's Test } \\
\text { for Equality of } \\
\text { Variances }\end{array}$} & \multicolumn{7}{|c|}{ t-test for Equality of Means } \\
\hline & & & & \multirow[b]{2}{*}{$\mathrm{t}$} & \multirow[b]{2}{*}{ Df } & \multirow{2}{*}{$\begin{array}{c}\text { Sig. } \\
\text { (2-tailed) }\end{array}$} & \multirow{2}{*}{$\begin{array}{c}\text { Mean } \\
\text { Difference }\end{array}$} & \multirow{2}{*}{$\begin{array}{l}\text { Std. Error } \\
\text { Difference }\end{array}$} & \multicolumn{2}{|c|}{$\begin{array}{c}95 \% \text { Confidence Interval } \\
\text { of the Difference }\end{array}$} \\
\hline & & $\mathrm{F}$ & Sig. & & & & & & Lower & Upper \\
\hline Pretest & $\begin{array}{l}\text { Equal } \\
\text { variances } \\
\text { assumed } \\
\text { Equal } \\
\text { variances } \\
\text { not } \\
\text { assumed }\end{array}$ & 3.675 & .059 & $\begin{array}{l}-.586 \\
-.565\end{array}$ & 59.945 & .559 & -.909 & 1.551 & -3.995 & 2.177 \\
\hline
\end{tabular}

The value of Leneve test results for homogeneity is the same as the above, which is homogenized. Because it is homogeneous, it is used the first line of T-count-. 586 value at DF 81. DF on this counting $T$ test can be compared with $T$ table on Df 81 and probability 0.05 For testing hypothesis in two ways is to compare between calculated positive values (there is a meaningful difference when $\mathrm{T}$ count $>$
$T$ table) and when the negative count Nilat (there is a meaningful difference when $\mathrm{T}$ count $<\mathrm{t}$ table) while the second way is to look at the value of sig (2 tailed) or P value. In the case of the above P value of 0559 where the $<0.05$ is due to the $<0.05$ then the difference is statistic or significantly significant at a probability of 0.05 .

Table 3. Independent Sample t-test of Post-test

Independent Samples Test

\begin{tabular}{|c|c|c|c|c|c|c|c|c|c|c|}
\hline & & \multicolumn{2}{|c|}{$\begin{array}{l}\text { Levene's Test } \\
\text { for Equality of } \\
\text { Variances }\end{array}$} & \multicolumn{7}{|c|}{ t-test for Equality of Means } \\
\hline & & \multirow[b]{2}{*}{$\mathrm{F}$} & \multirow[b]{2}{*}{ Sig. } & \multirow[b]{2}{*}{$\mathrm{t}$} & \multirow[b]{2}{*}{ df } & \multirow{2}{*}{$\begin{array}{c}\text { Sig. } \\
\text { (2-tailed) }\end{array}$} & \multirow{2}{*}{$\begin{array}{c}\text { Mean } \\
\text { Difference }\end{array}$} & \multirow{2}{*}{$\begin{array}{l}\text { Std. Error } \\
\text { Difference }\end{array}$} & \multicolumn{2}{|c|}{$\begin{array}{l}\text { 95\% Confidence Interval of the } \\
\text { Difference }\end{array}$} \\
\hline & & & & & & & & & Lower & Upper \\
\hline $\begin{array}{l}\text { Post } \\
\text { test }\end{array}$ & $\begin{array}{l}\text { Equal } \\
\text { variances } \\
\text { assumed } \\
\text { Equal } \\
\text { variances } \\
\text { not } \\
\text { assumed }\end{array}$ & .000 & .996 & $\begin{array}{c}13.220 \\
13.220\end{array}$ & 48 & .000 & 13.48000 & 1.01967 & 11.42981 & 15.53019 \\
\hline
\end{tabular}


The value of Leneve test results for homogeneity is the same as the above, which is homogenized. Because it is homogeneous, it is used the first line of T-count value 13,202 at DF 48 . DF on this counting $\mathrm{T}$ test can be compared with $\mathrm{T}$ table on Df 81 and probability 0.05 For testing hypothesis in two ways is to compare between calculated positive values (there is a meaningful difference when $\mathrm{T}$ count $>\mathrm{T}$ table) and when the negative count Nilat (there is a meaningful difference when $\mathrm{T}$ count $<\mathrm{t}$ table) while the second way is to look at the value of sig (2 tailed) or $\mathrm{P}$ value. In the case of the above $\mathrm{P}$ value of 0.000 where $>0.05$ because $>0.05$ then the differences are meaningful statistic or significantly at a probability of 0.05 .

\section{Conclussion}

Based on the results of the calculation that has been elaborated and explanation that has been concluded, among others: (1) There is a difference between the minimum and maximum values on Pretest and post-test for experimental classes. On (pre-Test) 70.60 while for the value on the pot-test 81.80. (2) on Pretest and post-test for the control class the average value (pre-Test) 70.00 while for the value on the pot-test 70.00. (3) for the T-Test grade in Experimemtal T-Test value $0.000<0.005$ can be concluded that there is a difference of ability and achievement of students before and after given treatment in this case is the application of Joyfull learning strategy To increase the interest and achievement of learning English students at STIE Yapman Majene.

\section{REFERENCES}

Azhar Arsyad (2007) Dasar-dasar penguasaan bahasa Inggris Lewat Your Basic Vocabulary. PT. RajaGrafindo Persada. IAIN Makassar

Aswad, Muhammad. 2017. "The Effectiness English Camp (A Model in Learning English as the Second Language)." ASEAN/Asian Academic Society International Conference Proceeding Series 0 (0). http://aasic.org/proc/aasic/article/view/297.

Husaini Algoyani (www.kompasiana.com). Diakses pada tanggal 29 Agustus 2018

Ramit Ring. (2008). Humor in Teaching. This paper was completed and submitted in partial fulfillment of the Master Teacher Program, a 2-year faculty professional development program conducted by the Center for Teaching Excellence, United States Military Academy, West Point, NY, 2008.

Rebekka Krause. (2014). Humour - An 'Important Spice to Use in Teaching?? On Humour and Its Uses in English as a Foreign Language Classrooms. Freie Universität Berlin. Institut für Englische Philologie. Didaktik des Englischen. Modul: Kompetenzorientierung im Englischunterricht II. SI: Theorieg. Forschen u. Handeln- Brücke zw. Praxis u. Theorie. Wintersemester 2014/15. Dozentin: Univ.-Prof. Dr. Michaela Sambanis.

Rima Aboudan. Laugh and Learn: Humor and Learning a Second Language. International Journal of Arts and Sciences 3(3): 90 - 99 (2009) CD-ROM. ISSN: 1944-6934 (C) InternationalJournal.org

Sue S. Minchew and Peggy F. Hopper. (2008). Teaching for Using Humor and Fun in the Language Arts Classroom. Sue S. Minchew, $\mathrm{PhD}$, is an associate dean of education and professor of curriculum and instruction at Mississippi State University. Peggy E Hopper, $\mathrm{PhD}$, is an assistant professor of curriculum and instruction in secondary English education at Mississippi State University. Copyright' 2008 Heldref Publications

Nancy. D. Bell. (2009). Learning about and through Humor in the Second Language Clasrroom. Washinton State University. Language Teaching Research 13,3 (2009); pp. 241-258 